\title{
MEDIA LITERACY AS A BASIC KNOWLEDGE FOR TEACHERS IN ELEMENTARY SCHOOL
}

\author{
Frederik Masri GASA ${ }^{1^{*}}$, Adhi Murti C. AMALIA ${ }^{2}$
}

${ }^{1}$ Communication Science Department, Faculty of Economics \& Communication Bina Nusantara University, Jakarta, Indonesia ${ }^{2}$ Public Relations Department, Faculty of Economics \& Communication Bina Nusantara University, Jakarta, Indonesia *frederik.gasa@binus.edu

\begin{abstract}
The high penetration of the Internet and social media among young people is a serious concern for all groups, including teachers at the elementary school level. Media literacy at the elementary school level becomes the foundation or fundamentals in preparing young people, especially elementary students in facing the increasingly changing environment in the current information age. Media literacy for educators, especially teachers at the elementary school level is a must amid the current wave of information and technology. Teachers at Tirtomoyo 1 Elementary School are parents of students who are responsible for education or media literacy. Media literacy for elementary school children is an important way and strategy in counteracting the flow of negative information circulating through social media. This activity is expected to be beneficial for teachers and students of Tirtomoyo 1 Elementary School in understanding how to use social media responsibly.
\end{abstract}

Keywords: Literacy, Media, Teacher, Elementary School

\section{BACKGROUND}

Internet penetration in Indonesia is increasing from year to year seen from the number of internet users. In January 2020, the number of internet users in Indonesia was 175.4 million, an increase of 17 percent or as many as 25 million people from the previous year. The increase in the number of internet users is directly proportional to the increase in the number of social media users. There was an increase of 8 percent or as many as 12 million people from the previous year (Kemp, 2020). These datas illustrate how big the influence of the internet, especially social media, in the lives of Indonesian people today.

The high number of internet and social media users in Indonesia has given rise to new anxiety, namely the increase in hoax terror. The Research and Development Agency of the Ministry of Home Affairs in 2018 stated that as many as 44 percent of Indonesians were unable to detect hoaxes that were disseminated through social media, especially Facebook, WhatsApp, and Instagram (Litbang.kemendagri.go.id, 2018).

Hoax or information that is not true is received by the public in various forms. A survey conducted by the Indonesian Telematics Society (Mastel) in 2019 to 914 respondents showed several forms of hoax content that were often received, the top 5 of which were socio-political (93.20\%), SARA (76.20\%), government $(61,7 \%)$, health (40.7\%), and food \& beverage (30\%). The results of the same survey show data on the reasons why people are still easily exposed to hoaxes, namely a) because the news is obtained from trustworthy people, b) because the sentences are convincing, c) because they are influenced by political choices/campaigns/affiliations/organizations, and d) because they are carried away hate speech (Mastel.id, 2019).

It is interesting to look at the first reason - because of receiving news from a trusted person, can only be overcome if the person who has been trusted has good media literacy skills, so that the interpretation of the message content in an information is not wrong. People who are trusted in society are usually because they have the ability, knowledge, or occupy the highest structure in society. Teachers are part of a group that has earned the trust of the community because of their noble duties, educating and educating the nation's generation. When teachers have a strong foundation of media literacy, students will get valuable supplies in dealing with the current situation where society is flooded with information every day. This is what prompted us to carry out community service activities for teachers at SDN Tirtomoyo 1 Malang so that students are ultimately able to grow and develop into a generation that is not only literate in reading and writing but also literate in media.

Alcott \& Gentzkow defines hoax as fake news, which focuses on the intentional spread of news that is proven to be false. Usually, the distribution of hoax news is often associated with political goals, such as intentionally being done to defame a political candidate (Allcott \& Gentzkow, 2017).

Hoax can be classified into 3 categories, which are called misinformation, malinformation, and disinformation. Misinformation means errors in information that are not always created to cause harm. Rumors or misinterpretations are examples of misinformation. Meanwhile, malinformation is misinformation that is intentionally done with the intention of causing harm.

Usually, malinformation occurs because of information leakage, and sometimes it leads to words that have the tone of harassment/harassment, and encourages hatred in the public. For example, getting an email about a politician's scandal and then using it to bring down the politician. Finally, disinformation is a combination of misinformation and malinformation. In particular, disinformation displays fake context, fake content, and manipulated or falsified content (Wardle \& Derakhshan, 2017).

Disinformation can come from unintentional sources (misinformation), or from sources that are intentional to create harm (malinformation). For example, there are 
individuals who misinterpret a politician's speech related to religion, then spread it as hoax news that the politician hates a certain religion so that the politician will not be reelected in the next period.

Media literacy is formed from 3 building blocks, namely skills, knowledge, and personal locus. Skills are tools used to build knowledge, and it is this knowledge structure that organizes what has been learned and is directed by a personal locus (Potter, 2016). Potter concludes that media literacy is a set of perspectives that are used to expose, process and interpret the meaning of the messages we receive. The meaning of literacy is no longer limited to the ability to read and write, but also the ability to interpret the meaning of a message.

Messages are now not only obtained from written sources such as books, newspapers, or magazine articles, but are also found in television or film media, which is called visual literacy. Furthermore, from reading literacy which shifted to visual literacy, it developed again into computer literacy. More messages can be obtained through the internet, social media, and much more. Media literacy then combines all these media so that it is known to be something more general. In essence, media literacy can be interpreted as the ability to interpret the meaning obtained from various existing media, including digitalbased media.

Potter (2001: 10) says that individuals with low literacy levels will easily accept the meanings created and determined by the media (Sabrina, 2019). These individuals tend to have shallow knowledge structures and are less organized, so that they have limited perspectives and are unable to interpret the meaning of media messages in more depth. Meanwhile, individuals with a high literacy level have a broader knowledge structure and perspective, so they are able to select and interpret messages well.

In the context of education, especially basic education, media literacy competencies are important to learn and develop. Hobbs (2010) states that there are five competencies in media literacy, namely access, action/ agency, reflection, creation and analysis and evaluation (McDougall et al., 2018).

The competence to access media refers to the ability to find and use media and ICT tools skilfully, including the ability to share suitable and helpful information with others. Accessing media and digital technology in the classroom and working with multimodal media texts can help students to compose and organise ideas, design, produce and present meaning.

Analysis and evaluation competences refer to the capacity to understand media messages and use critical thinking to analyse their quality, veracity, credibility, and point of view, while considering their potential effects or consequences. Media literacy education can enable students to make connections between a specific media form and the wider socioeconomic and cultural context in which the media in question was produced and consumed.
The production of media content can be a powerful means of learning, if adequately combined with critical reflection and analysis. Media literacy interventions that include active audience involvement components (e.g. creative production activities or classroom discussions) have been found to be more effective than interventions based solely on passive components (e.g. lessons only), as they require greater mental efforts and comprehension.

Media literacy competences are necessary to act and participate in society as they enable citizens to access, understand and engage with the media, and to become political agents in a democratic society. They can allow students to use their voices through active participation in online activities and facilitate students' active citizenship competences and agency to express their politics and to participate in the public sphere (McDougall et al., 2018).

\section{METHODS}

This community service activity is carried out online on April 15, 2020. In carrying out it, there are several stages that must be carried out, including the following:

a. Visited SD Negeri Tirtomoyo 1 to meet the teachers. The team visited SD Negeri Tirtomoyo 1 to socialize the program with the teachers, and discuss if there were any suggestions before the service activities were carried out.

b. Selected several teachers of SD Negeri Tirtomoyo 1 as the subject of devotion. The team selected several teachers of SD Negeri Tirtomoyo 1 who would participate in the program so that program recipients could be distributed evenly and on target.

c. Determine the schedule of service activities with the subject of service. The team looked for a suitable schedule with the teachers of SD Negeri Tirtomoyo 1 so that it would not interfere with the teaching and learning process and the program could be implemented properly. This phase a-c was carried out in February and March 2020 before the Covid-19 protocol rules regarding social distancing were implemented.

d. Carry out service activities at SD Negeri Tirtomoyo 1. The team will hold service activities at SD Negeri Tirtomoyo 1 regarding the importance of media literacy as one of the skills and abilities that must be possessed today, so that teachers are also able to teach the same thing to students.

e. Evaluating the implementation of activities through surveys given to participants. This is so that the team can obtain an assessment from the participants regarding the service activities carried out so that it can be used as a reference for the team for the implementation of further activities.

Data collection in service activities is carried out using observation and interview techniques. The service team made direct observations in the field, in this case SDN Tirtomoyo I then interviewed the principal and 
several existing teachers to obtain an overview of the problems related to the topic of this service.

\section{RESULT AND DISCUSSION}

When doing online training, there are some interesting things that are found. First, the majority of teachers at SDN 1 Tirtomoyo have often heard the term media literacy but conceptually do not really understand it. The lack of understanding of the concept of media literacy can indirectly affect how teachers educate students on how to use social media wisely. Teachers are well aware that media literacy education must be provided to students from an early age so that anxiety and fear of the dangers of exposure to information on social media can be overcome.

Second, the anxiety and fear of the teachers are certainly well-founded, especially since the students at SDN 1 Tirtomoyo are quite familiar with the use of digital technology and the internet. Many students bring smartphones to school, operate them to communicate with their friends, or use them to support teaching and learning activities, or just looking for entertainment. Fluency in using this smartphone must be balanced with good media literacy skills so that it does not have a bad impact on the student.

Efforts to educate media literacy from an early age are considered very important considering that students are still relatively very young and do not have sufficient knowledge of the dangers that can result from the current use of technology and social media. Information and other content that is freely circulated through social media must still be filtered so that social media can have a positive impact on student growth and development. Teachers have a responsibility as role models for students so it has become a must if teachers are able to show how to use social media properly and correctly.

Teachers are aware that there will be many challenges in teaching media literacy education to students. One of them is the limitations of teachers in supervising students in using their smartphones and social media. Supervision will only be maximized when students are in the school environment, while when students are outside school, especially during a pandemic like today, it will be very difficult to control it. Teachers collaborate with parents to be able to supervise students in using social media. Controlling the activities of students in cyberspace is the task of teachers and parents so that although the ability to interpret students' messages is still very low, teachers and parents are at the forefront in supervising and guiding these students.

The ability of children to interpret the meaning of a message is still very limited, so that children are vulnerable to using the internet unwisely, for example, being consumed by hoaxes that are widely circulated on the internet. This low level of literacy can be seen when children disclose information they get from the media or the internet, and how they discuss it at school with their friends. Often the opinions that arise from these children are not in accordance with the actual reality on the ground. Children tend to immediately believe what they find on the internet and there is no desire to double-check or find facts that support the truth of the information. This can be fatal because children not only have the potential to consume hoax news, but can also become hoax spreaders.

Grizzle (2011) says that the introduction of literacy in the academic world should start early, it can even be included in the curriculum. Therefore, it is necessary to have academic literacy that also targets teachers, because teachers are the main source for students to get information at school. If the understanding of literacy can be started from teachers who can critically evaluate the information circulating, it is hoped that there will be a positive transfer of knowledge to their students. Teachers can play an important role in instilling this knowledge structure in children, so that children can have good media literacy skills and use the internet wisely and are not easily influenced by hoaxes.

\section{CONCLUSION}

Media literacy is conceptually not quite familiar to the teachers at SDN Tirtomoyo I, but in a practical setting, these teachers already understand the essence of media literacy. The teachers agree that good media literacy will help to produce a young generation that is tough and wise in the current era of digital technology advancement. This service activity is expected to be able to trigger other similar activities in the future so that the community, especially educators, have strong media literacy skills.

\section{ACKNOWLEDMENT}

This service activity can take place thanks to the support of the Community Development Academic unit of Bina Nusantara University. The researcher would also like to thank the Principal and the teachers of SDN Tirtomoyo 1 for their willingness to participate in this activity.

\section{REFERENCES}

Allcott, H., \& Gentzkow, M. (2017). Nber Working Paper Series SocialMediaandFakeNewsinthe2016Election. Journal of Economic Perspectives, 31(2), 211-236. http://www.nber.org/papers/w23089\%0Ahttp://www. nber.org/papers/w23089.ack

Kemp, S. (2020). Digital 2020: Indonesia. https:// datareportal.com/reports/digital-2020-indonesia

Litbang.kemendagri.go.id. (2018). Riset: 44 Persen Orang Indonesia Belum Bisa Mendeteksi Berita Hoax. http://litbang.kemendagri.go.id/website/riset44-persen-orang-indonesia-belum-bisa-mendeteksiberita-hoax-2/

Mastel.id. (2019). Hasil Survey Wabah Hoax Nasional 2019. https://mastel.id/hasil-survey-wabah-hoaxnasional-2019/ 
Potter, W. J. (2016). Media Literacy Eighth Edition. In Sage Publications, Inc.

Sabrina, A. R. (2019). Literasi Digital Sebagai Upaya Preventif Menanggulangi Hoax. Communicare: Journal of Communication Studies, 5(2), 31. https:// doi.org/10.37535/101005220183
Wardle, C., \& Derakhshan, H. (2017). Information Disorder: Toward an interdisciplinary framework for research and policy making. Report to the Council of Europe, 108. https://rm.coe.int/informationdisorder-toward-an-interdisciplinary-frameworkfor-researc/168076277c 